9 Junghard O, Lauritsen K, Talley NJ, Wiklund IK. Validation of 7-graded diary cards for severity of dyspeptic symptoms in patients with non-ulcer dyspepsia. Eur J Surg 1998;164(suppl 583):106-11.

10 Jaeschke R, Singer J, Guyatt GH. Measurement of health status. Ascertaining the minimal clinically important difference. Controlled Clin Trials $1989 \cdot 10 \cdot 407-15$

11 Wiklund IK, Junghard O, Grace E, Talley NJ, Kamm M, Veldhuyzen van Zanten SJO, et al. Quality of life in reflux and dyspepsia patients. Psychometric documentation of a new disease-specific questionnaire (QOLRAD). Eur J Surg 1998;164(suppl 583):41-9.

12 Drummond MF, O'Brien B, Stoddart GL, Torrance GW. Cost benefit analysis. In: Methods for the economic evaluation of health care programmes. New York: Oxford Medical Publications, Oxford University Press, 1997:205-31.

13 Labour force and unpaid work of Canadians: selected labour force, demographic, cultural, educational and income characteristics by sex (based on the 1991 standard occupational classification) for Canadian provinces, territories and CMAs, 1996 census (20\% sample data). Ottawa, Canada: Statistics Canada, 1996.

14 Thompson SG, Barber JA. How should cost data in pragmatic randomised trials be analysed? $B M J$ 2000;320:1197-200.

15 Vinod HD. Bootstrap methods: applications in econometrics. In: Maddala GS, Rao CR, Vinod HD, eds. Handbook of statistics 11:econometrics. Elsevier Science, Chapman and Hall, CRC, 1993:629-61.

16 Huang JQ, Sridhar S, Chen Y, Hunt RH. Meta-analysis of the relationship between Helicobacter pylori seropositivity and gastric cancer. Gastroenterology 1998;114:1169-79.
17 Bayerdörffer E, Neubauer A, Rudolph B, Thiede C, Lehn N, Eidt S, et al. Regression of primary gastric lymphoma of mucosa-associated lymphoid tissue type after cure of Helicobacter pylori infection [see comments]. Lancet 1995;345:1591-4.

18 Laine L, Schoenfeld P, Fennerty MB. Therapy for Helicobacter pylori in patients with nonulcer dyspepsia. A meta-analysis of randomized, controlled trials. Ann Intern Med 2001;134:361-9.

19 Moayyedi P, Soo S, Deeks J, Forman D, Mason J, Innes M, et al. Systematic review and economic evaluation of Helicobacter pylori eradication treatment for non-ulcer dyspepsia. BMJ 2000;321:659-64.

20 Talley NJ, Stanghellini V, Heading RC, Koch KL, Malagelada JR, Tytgat GN. Functional gastroduodenal disorders. Gut 1999;45(suppl 2):II37-42.

21 Tytgat GN. GERD remains an intriguing enigma. Gastroenterology 2001;120:787.

22 McColl KEL, Dickson A, El-Nujumi A, el-Omar E, Kelman A. Symptomatic benefit 1-3 years after $\mathrm{H}$. pylori eradication in ulcer patients: impact of gastroesophageal reflux disease. Am J Gastroenterol 2000;95:101-5.

23 Moayyedi P, Bardhan C, Young L, Dixon MF, Brown L, Axon AT. Helicobacter pylori eradication does not exacerbate reflux symptoms in gastroesophageal reflux disease. Gastroenterology 2001;121:1120-6.

24 Chiba N, Veldhuyzen van Zanten SJO, Grace EM, Sinclair P, Simons WR, Lee JSM. The cost-effectiveness of a test and treat approach in primary care patients. Gut 2000;47(suppl 1):A113-4.

(Accepted 25 January 2002)

\title{
Quitting and restarting smoking: cohort study of patients with angina in primary care
}

\author{
Mairead Corrigan, Margaret E Cupples, Mike Stevenson
}

Department of General Practice, Queen's University, Belfast BT9 7HR

Mairead Corrigan postdoctoral research fellow

Margaret E Cupples senior lecturer

Department of Epidemiology and Public Health,

Queen's University, Belfast BT9 5EE

Mike Stevenson

lecturer in medical statistic

Correspondence to: M Corrigan m.corrigan@ qub.ac.uk

BMJ 2002;324:1016-7

Smoking is the most important modifiable risk factor for coronary heart disease and its reduction is a target for primary health care. ${ }^{1}$ The participants in most studies of the smoking habits of patients with coronary heart disease are enrolled after acute cardiac events. ${ }^{2}$ There are few documented studies of the changes in the smoking habits of patients with angina. This study examined variations in self reported smoking habits over a five year period in a primary care cohort of patients diagnosed as having angina.

\section{Participants, methods, and results}

Patients clinically diagnosed as having angina at least six months previously were identified from the disease registers of 18 general practices in the Greater Belfast area. These general practices were chosen to represent the diversity of socioeconomic classes and cultures in the area. All patients who agreed to participate in a randomised controlled trial of health education were interviewed at baseline, at two years, and at five years. Those who did not complete the review at two years were not contacted at five years.

Self reported cigarette smoking among 487 patients with angina

\begin{tabular}{|c|c|c|c|c|}
\hline \multirow[b]{2}{*}{ Smoking behaviour } & \multicolumn{3}{|c|}{ Smoking status } & \multirow[b]{2}{*}{ Total $(\% ; 95 \% \mathrm{Cl})$} \\
\hline & At baseline & At 2 years & At 5 years & \\
\hline Continued non-smoking & Non-smoker & Non-smoker & Non-smoker & $374(77 ; 73$ to 81$)$ \\
\hline Continued smoking & Smoker & Smoker & Smoker & $58(12 ; 9$ to 15$)$ \\
\hline \multirow{3}{*}{$\begin{array}{l}\text { Baseline non-smoking }(n=21) \\
\text { and change in smoking habit }\end{array}$} & Non-smoker & Non-smoker & Smoker & $4(0.8 ; 0.2 \text { to } 2.1)^{*}$ \\
\hline & Non-smoker & Smoker & Non-smoker & $8(1.6 ; 0.7 \text { to } 3.2)^{*}$ \\
\hline & Non-smoker & Smoker & Smoker & $9(1.8 ; 0.8 \text { to } 3.5)^{*}$ \\
\hline \multirow{3}{*}{$\begin{array}{l}\text { Baseline smoking }(n=34) \text { and } \\
\text { change in smoking habit }\end{array}$} & Smoker & Smoker & Non-smoker & $18(3.7 ; 2.2 \text { to } 5.8)^{*}$ \\
\hline & Smoker & Non-smoker & Smoker & $4(0.8 ; 0.2 \text { to } 2.1)^{\star}$ \\
\hline & Smoker & Non-smoker & Non-smoker & $12(2.4 ; 1.3 \text { to } 4.3)^{*}$ \\
\hline
\end{tabular}

Confidence limits based on exact Poisson probabilities.
Participants were questioned about their smoking habits. Smokers were defined as those who smoked at least one cigarette daily. Full details of the method are reported elsewhere. ${ }^{34}$

A cohort of 487 patients completed the five year follow up. Of these, $58 \%(284 / 487)$ were male and $44 \%$ (213) belonged to socioeconomic groups IV and V (11\% (56) were in groups I and II, and 45\% (219) were in group III). The mean participant age was 63 (range 38-74; SD 7) years.

Before recruitment $12 \%$ (58) of participants had been diagnosed as having angina for six months to one year, $36 \%$ (174) two to five years, $23 \%$ (115) six to ten years and $29 \%$ (140) up to 33 years. Over three quarters of participants (374, 77\% $\quad(95 \%$ confidence interval $73 \%$ to $81 \%)$ ) continued as non-smokers and $58(12 \%, 9 \%$ to $15 \%)$ persisted in smoking (table). Of the 395 participants who were baseline non-smokers, $21(5 \%, 3 \%$ to $7 \%)$ subsequently reported smoking. Of the 92 self reported smokers at baseline, $34(37 \%, 27 \%$ to $47 \%)$ subsequently reported non-smoking.

Fifty five participants $(11 \%, 8 \%$ to $14 \%)$ changed their smoking habits over the five year period. At baseline, ever having smoked was reported by 346 (71\%, $67 \%$ to $75 \%$ ) participants. Of the 21 baseline non-smokers who changed their smoking habits over the five year period, 18 had, previous to this study, smoked cigarettes and two had smoked cigars or a pipe.

Among those who at baseline reported having stopped smoking cigarettes for less than one year, 1 to 5 years, and more than 5 years, $5 / 16(31 \%, 7 \%$ to $55 \%)$, $4 / 33$ (12\%, $1 \%$ to $23 \%)$, and $9 / 184(5 \%, 3 \%$ to $7 \%)$ subsequently resumed smoking, respectively. 


\section{Comment}

Participants in this cohort of patients with angina restarted smoking more than five years after having quit. Such longitudinal changes in self reported smoking status indicate that patients may resume smoking after lengthy periods of abstinence. Periodic inquiry regarding smoking habit is, therefore, worthwhile.

Since more than a third of self reported smokers subsequently reported quitting there is value in promoting smoking cessation among patients with established cardiovascular disease. Similar cycles of abstinence and relapse have been reported in other study populations ${ }^{5}$; this emphasises the importance of long term follow up in evaluating interventions.

Contributors: MEC initiated the idea for the study and contributed to the design, analysis, interpretation, and writing of the paper. MC participated in the analysis, interpretation, and writ- ing of the paper. MS contributed to the design and provided statistical information.

MEC and MC are guarantors.

Funding: The Medical Research Council funded the two year review. The Northern Ireland Chest Heart and Stroke Association funded the five year review.

Competing interests: None declared.

1 Department of Health. Coronary heart disease: national service framework for coronary heart disease:modern standards and service models. London: Stationery Office, 2000.

2 Rosal MC, Ockene JK, Hebert JR, Merriam P, Hurley TG. Coronary artery smoking intervention study (CASIS): 5-year follow-up. Health Psychol 1998; 17:476-8

3 Cupples ME, McKnight A. Randomised controlled trial of health promotion in general practice for patients at high cardiovascular risk. $B M J$ 1994;309:993-6.

4 Cupples ME, McKnight A. Five year follow up of patients at high cardiovascular risk who took part in a randomised controlled trial of health promotion. BMJ 1999:319:687-8

5 Ockene JK, Emmons KM, Mermelstein RJ, Perkins KA, Bonollo DS, Voorhees CC, et al. Relapse and maintenance issues for smoking cessation. Health Psychol 2000;19:17-31

(Accepted 27 September 2001)

\section{A paper that changed my life Dishing the dirt}

The postwar medical achievement is so eloquent a testimony to the power of science as to make scientific materialists of us all. Few doubt any longer that the natural world in all its wonder and complexity must ultimately be knowable. And just as the power of human reason provided-through the discovery of antibiotics - the means to combat the blight of infectious disease, so too it must inevitably provide explanations and solutions for all that is still obscure.

And so I thought too until a couple of years ago, when I stumbled across a paper from 1961 by the great Selman Waksman, winner of the Nobel Prize for his discovery of streptomycin. ${ }^{1}$ Its title, "The role of antibiotics in nature," may seem innocent enough, but the conclusions are deeply and disturbingly subversive.

Selman Waksman was born in the Ukraine in 1888 and grew up with two passions-for his mother and the land. "The odour of the black soil so filled my lungs I could never forget it," he observed in his autobiography. And, indeed, he never did, for, after emigrating to the United States, he enrolled at Rutgers Agricultural College in New York to study soil science and the low life that inhabits it, and one species in particular, the actinomyces. Within a decade, and while still in his 30 s, he had published his monumental 900 page Principles of Soil Microbiology.

Waksman was struck by a paradox. The soil teems with microbial life-an estimated and astonishing three billion per gram-and yet "one can only wonder that it harbours so few capable of causing infectious disease in animals and man." Might it be that in their struggle for survival within the soil these human pathogens were destroyed by chemicals produced by other species of bacteria? These chemicals-and Waksman was the first to coin this term-would be "antibiotics," literally "against life."

In 1940, a year before Florey and Chain rediscovered penicillin, Waksman initiated a systematic search for these antibiotics, though he could never have anticipated that his own chosen species, the actinomyces, would prove to be the source of so many antibiotics currently in clinical use-including streptomycin, chloramphenicol, tetracycline, erythromycin, nystatin, and vancomycin.

Waksman donated the substantial royalties from his discovery of streptomycin to his alma mater, Rutgers, to found an institute of microbiology, of which he became the first director. But his continuing research into the mechanism of action of antibiotics over the next two decades persuaded him his original "chemical warfare" theory that had so successfully predicted the discovery of antibiotics must, none the less, be in error. He explained why in "The role of antibiotics in nature."

Antibiotics, he pointed out, could not have a central role in microbes' struggle for survival because their concentration in the soil was quite insufficient to destroy other bacteria. Further, he noted, "specific nutrients characteristic for each organism are a sine qua non requirement for the production of antibiotics but such nutrients are never found in proper combination or sufficient concentrations to enable the antibiotic-producing organisms to dominate their environment." Antibiotics were, in short, "a Petri dish phenomenon" because they could reliably be extracted in biologically significant quantities only in the laboratory. So, if antibiotics were not chemical warfare weapons deployed by the actinomyces to maximise their chance of survival in the soil, what could their "role in nature" possibly be? Waksman, who, it must be emphasised, knew more about the ecology of soil microbes than anyone before or since, concluded that they were "a purely fortuitous phenomenon ... there is no purposefulness behind them."

Surely not. It cannot be that microbes should have the potential to create these diverse and complex compounds and yet apparently gain no advantage from them. But could one not say the same about the thousands of other naturally occurring compounds discovered by humanity and turned to its advantage? What benefits the willow tree that its bark should contain salicylic acid; or the foxglove, digitalis; the periwinkle, vincristine; or the poppy, opiates? Certainly we may wish to infer the purpose of these chemicals produced by plants and microbes is to maximise their chances of survival. But this is just a "façade of knowing," behind which we can deceive ourselves into thinking we understand more than we really do.

Sixty years on, the role of antibiotics in nature remains as inscrutable as ever. They are the mystery of mysteries of modern medicine. So much for scientific materialism.

James Le Fanu retainer general practitioner, Mawbey Brough Health Centre, London SW8 2UD

1 Waksman S. The role of antibiotics in nature. Perspectives in Biology and Medicine 1961;4(3):271-2.

We welcome articles up to 600 words on topics such as A memorable patient, A paper that changed my practice, My most unfortunate mistake, or any other piece conveying instruction, pathos, or humour. If possible the article should be supplied on a disk. Permission is needed from the patient or a relative if an identifiable patient is referred to. We also welcome contributions for "Endpieces," consisting of quotations of up to 80 words (but most are considerably shorter) from any source, ancient or modern, which have appealed to the reader. 